\title{
Разработка вакцины против коронавирусной инфекции на базе норовирусной молекулярной платформы
}

Новиков Д.В., Мохонов В.В., Мохонова Е.В., Лапин В.А., Мелентьев Д.А., Новиков В.В.* Нижегородский научно-исследовательский институт эпидемиологии и микробиологии им. академика И.Н. Блохиной, Роспотребнадзора, Нижний Новгород, Российская Федерация. *e-mail: mbre@mail.ru

Резюме: Известно, что белок норовируса VP1 способен самостоятельно собираться в вирусоподобные частицы (ВПЧ), на которые развивается достаточно сильный иммунный ответ. Нами получен рекомбинантный VP1 эпидемического варианта норовируса генотипа GII.4, доминировавшего на территории Нижегородской области в 2018 г. Показана способность VP1 к самосборке, его безопасность и иммуногенность. ВПЧ на основе VP1 норовируса использованы в качестве молекулярной платформы для разработки вакцины против коронавирусной инфекции. Для этого проведена замена части белка VP1, экспонированной на поверхности ВПЧ, на аминокислотную последовательность SARS-CoV-2, кодирующую сайты связывания с рецепторами (RBD). Для увеличения растворимости и корректного фолдинга N-концевая часть рекомбинантной химеры VP1 норовируса с RBD SARS-CoV-2 слита с периплазматическим мальтозосвязывающим белком E.coli с включением сайта для специфичного гидролиза. Проведена оптимизация экспрессии, растворения и очистки слитого белка VP1 норовируса с RBD SARS-CoV-2. Полученная химерная структура может быть использована в составе вакцины для профилактики COVID-19, применимой для интраназальной вакцинации.

При разработке вакцин применяют разные стратегии, каждая из которых имеет свои преимущества и недостатки. Используется инактивация цельных вирионов, подбор живых аттенуированных штаммов, иммунизация пептидами, вирусоподобными частицами (ВПЧ) и нуклеиновыми кислотами. Инактивированные и аттенуированные вакцины являются высокоиммуногенными препаратами. Ограничением является дороговизна производства и возможность репликации вакцинных штаммов, реассортации или рекомбинации генома вакцинных штаммов с диким вирусом. Пептидные вакцины легко конструируются с использованием генетических технологий и нарабатываются в микроорганизмах. Однако их использование ограничено слабой иммуногенностью и сложностями в формировании конформационных детерминант для нейтрализующих 
антител. ВПЧ совмещают в себе преимущества описанных выше стратегий. Структурно повторяя вирион, ВПЧ характеризуются высокой иммуногенностью, содержат конформационные детерминанты для нейтрализующих антител и не содержат в своем составе вирусных нуклеиновых кислот. Белковые компоненты ВПЧ достаточно легко нарабатываются и способны к самосборке в вирусоподобные частицы. Более того, ВПЧ могут выступать в качестве вектора для индукции иммунного ответа на искусственно встроенные в них антигены. Это свойство используется для создания универсальных платформ, позволяющих получать мультивалентные вакцины, содержащие различные антигенные детерминанты.

Нами в качестве платформы для конструирования вакцин использованы вирусоподобные частицы норовируса. Основным белком капсида норовирусов является VP1, мономеры которого димеризуются при экспрессии клетках прокариот или эукариот, а димеры VP1 самостоятельно собираются в ВПЧ, практически неотличимые от нативных вирионов. С использованием нуклеотидной последовательности эпидемического варианта норовируса генотипа GII.4, доминировавшего на территории Нижегородской области в 2018 г, была создана генетическая конструкция, кодирующая рекомбинантный VP1, сконструированы штаммы E. coli Rosetta 2 (DE3) и Rosetta 2/43 (DE3) AhpC, $\Delta$ SlyD/X, $\Delta \operatorname{TrxB}, \Delta$ Gor - продуценты рекомбинантного белка. Получен чистый препарат VP1, показана его способность к самосборке, безопасность и иммуногенность на лабораторных животных.

Структурно VP1 разделяется на домен S, формирующий оболочку вириона, и выступающие Р домены, содержащие сайты связывания с лигандами. Известно, что замена Р части белка VP1 на чужеродные последовательности, позволяет экспонировать интересующий антиген на поверхности ВПЧ [1]. Такие ВПЧ, способны вызывать сильный иммунный ответ на экспонированный антиген. Основанные на VP1 ВПЧ норовируса могут быть использованы в качестве молекулярной платформы для презентации различных антигенов и создания мультивалентных вакцин, включая SARS-CoV-2 [2]. В связи с этим мы использовали ВПЧ норовируса в качестве платформы для разработки интразальной вакцины для профилактики SARS-CoV-2. Известно, нейтрализующие антитела, предотвращающие инфицирование клеток хозяина, образуются на домен RBD белка Spike SARS-CoV-2 отвечающий за связывание с рецепторами Neuropilin-1 и ACE2 $[3,4]$. Имеющиеся наработки были использованы нами для дизайна генетической конструкции, кодирующей химерный белок, состоящий из S части VP1 норовируса, слитой с RBD SARS-CoV-2. 
На основе нуклеотидной последовательности SAR-CoV-2 (GenBank № MT188341) были подобраны олигонуклеотиды, фланкирующие регион, кодирующий сайты связывания с Neuropilin-1 и АCE2. Методом ОТ-ПЦР был синтезирован фрагмент кДНК, кодирующий RDB изолята SAR-CoV-2, циркулирующего на территории Нижнего Новгорода. Полученную кДНК использовали для получения двух генетических конструкций. Первая предназначена для получения в E. coli рекомбинантного белка RBD SARS-CoV-2, который применим в качестве антигена в иммуноферментном анализе. Вторая конструкция представляет собой химеру между отвечающим за самосборку норовирусной частицы S доменом VP1 и RBD SARS-CoV-2. Данная генетическая конструкция предназначена для получения рекомбинантного белка, способного формировать вирусоподобные частицы, презентирующие на своей поверхности RBD SARS-CoV-2. Были получены штаммы E. coli - продуценты рекомбинантных RBD SARSCoV-2 и химеры VP1 норовируса с RBD SARS-CoV-2. Для увеличения растворимости и корректного фолдинга полученных белков $\mathrm{N}$-концевые части рекомбинантного RBD SARS-CoV-2 и химеры VP1 норовируса с RBD SARS-CoV-2 были слиты с периплазматическим мальтозосвязывающим белком (MalE) E.coli (штамм K-12). Между MalE и целевым белком включен сайт для специфичного гидролиза протеазой TEV. Полученные штаммы использованы для наработки рекомбинантных белков. Проведена оптимизация экспрессии, растворения и очистки рекомбинантного RBD SARS-CoV-2 и химеры VP1 норовируса с RBD SARS-CoV-2. Первый использован в качестве антигена для выявления антител в крови переболевших COVID-19. Установлено, что рекомбинантный RBD распознается антителами, присутствующими в сыворотке крови переболевших SARS-CoV-2. На лабораторных животных проводятся испытания безопасности и иммуногенности химерного VP1 норовируса и RBD SARS-CoV-2, который потенциально может быть использован не только для внутримышечного, подкожного, но и для интраназального применения. Вероятной сферой использования такого препарата является профилактика инфицирования детей коронавирусом. Кроме того, разработка может быть эффективна для вакцинации пожилых лиц.

\section{Список литературы}

1. M. Xia, et al. Bioengineered Norovirus $S_{60}$ Nanoparticles as a Multifunctional Vaccine Platform. ACS Nano. 2018 Nov 27;12(11):10665-10682. doi: 10.1021/acsnano.8b02776. Epub 2018 Sep 25.

2. Y. Wang, et al. SARS-CoV-2 S1 is superior to the RBD as a COVID-19 subunit vaccine antigen. J Med Virol. 2020; 1-7. https://doi.org/10.1002/jmv.26320. 
3. L. Cantuti-Castelvetri, et al. Neuropilin-1 facilitates SARS-CoV-2 cell entry and infectivity. Science 13 Nov 2020: Vol. 370, Issue 6518, pp. 856-860. DOI: 10.1126/science.abd2985.

4. J. L. Daly, et al. Neuropilin-1 is a host factor for SARS-CoV-2 infection. Science 13 Nov 2020: Vol. 370, Issue 6518, pp. 861-865. DOI: 10.1126/science.abd3072. 